Agriculture, Agribusiness and Biotechnology

Vol.59: e16160061, January-December 2016 http://dx.doi.org/10.1590/1678-4324-2016160061 ISSN 1678-4324 Online Edition

BRAZILIAN ARCHIVES OF BIOLOGY AND TECHNOLOGY

AN INTERNATIONAL JOURNAL

\title{
Spore Germination and Protonemal Development of Dolichomitriopsis diversiformis
}

\author{
Shibiao Liu ${ }^{1 *}$; Hua Wei ${ }^{1}$; Xiaolie Peng ${ }^{1}$; Jing Li ${ }^{1}$. \\ ${ }^{1}$ Jishou University, Biology, Hunan, China.
}

\begin{abstract}
Dolichomitriopsis diversiformis is an endemic and threatened moss in eastern Asia. In vitro culture and light microscopic observation were employed to study its developmental process from spore germination to the formation of young gametophyte, as well as effects of light and temperature on its spore germination and protonemal development. Microscopic observations revealed that its spores were positively photoblastic with exosporous germination, and sporelings were classified as the bryum-type. Light and dark conditions were compared to understand their effects on spore germination. In $24 \mathrm{~h}$ continuous illumination, all spores germinated in both $20{ }^{\circ} \mathrm{C}$ and $25{ }^{\circ} \mathrm{C}$. In contrast, in darkness at $20^{\circ} \mathrm{C}$ from one to 30 days, spores did not germinate. However, when darkcultured spores transferred to continuous light, they started to geminate in 48 hours. In addition, effects of $20{ }^{\circ} \mathrm{C}$ and $25{ }^{\circ} \mathrm{C}$ on sporeling were compared. In a continuous light condition, sporelings grew longer and developed more protonema branches in the $20{ }^{\circ} \mathrm{C}$ treatment than in the $25{ }^{\circ} \mathrm{C}$ treatment. It was interesting that a phenomenon of slow and hysteretic spore germination and protonematal development was observed in natural light and room temperature $\left(5-10^{\circ} \mathrm{C}\right)$. These observations suggest that spore germination and sporeling development is regulated by light and temperature.
\end{abstract}

Key words: Dolichomitriopsis diversiformis, spore, protonema, light, temperature

\footnotetext{
${ }^{1}$ Authors for correspondence: liushibiao_1@163.com
} 


\section{INTRODUCTION}

Dolichomitriopsis diversiformis (Mitt.) Nog. of the Lembophyllaceae (Bryophyta) is a perennial, epiphytic and dioecious species native to eastern China, mainly distributing in Anhui, Guizhou, Sichuan and Zhejiang Provinces (Wu 1992; Bureau of National Environmental Protection 1998). In addition, this species is prevalent in Hokkaido, Nonshu, Shikoku and Yushu in Japan (Noguchi 1989). Although this moss species was an endemic species in those provinces in China, its prevalence has been threatened by climate change, air pollution and habitat destruction (Chen 1993). For example, its growth habitats on tree trunks in the altitudes from 1650 to $2080 \mathrm{~m}$ sea level have been destructed by deforestation.

We recently found this species in Fanjin Mountain (about $2570 \mathrm{~m}$ altitude sea level) in the Wuling Mountainous region (500-2570.5 m altitude sea level), Guizhou Province, China. The average annual temperature, precipitation and relative humidity in this region is $6-17{ }^{\circ} \mathrm{C}$ and $1100-2600$ $\mathrm{mm}, 80 \%$, respectively. This region is characterized by a typical monsoon montane humid midsubtropical climate, which allows a diverse vegetation and offers an appropriate growth environment for D. diversiformis (Zhou 1990). To date, certain types of researches have been completed to understand its natural habit (Liu et al. 2006), sexual reproduction (Liu et al. 2008), nutrient allocation to reproduction organs ( $\mathrm{Li}$ et al. 2009), and photosynthetic responses to light, temperature and plant water content (Li et al. 2004; Du et al. 2014). In addition, effects of cadmium on leaf cell damage and photosynthetic pigments have been investigated (Gong et al. 2010). These studies have provided information to understand its natural habitation for future preservation.

Spore germination and protonemal development are two important areas to understand moss biology. Particularly, moss protonemata are typical features to understand evolution of plant morphogenesis (Pressel et al. 2008; Alfayate et al. 2013) and plant development regulated by hormones (Bauer et al. 2007; Nowak et al. 2014). Meanwhile, studies on protonemata development can provide indirect information to conserve those endangered germplasm species, such as cryopreservation (Sabovljević et al. 2014; Wu et al. 2015).
To date, in vitro culture is a potent method to study cellular, developmental, reproductive and molecular biology of bryophytes. Furthermore, in vitro culture is successfully applied to study bryophyte systematics (Duckett et al. 2004). In the estimated 10 000-14 000 species of mosses, approximately one thousand have been investigated using this approach (Duckett and Ligrone 1992; Duckett et al. 2004; Hohe and Reski 2005; Mallón et al. 2006; Martinez and Price 2011; Zhang et al. 2011). These in vitro studies that had been completed include effects of different growth conditions on spore germination and protonemal development, such as light, temperature, moisture, and nutrient (Chopra and Bhatla 1981; Chaban et al. 1999; Silva et al. 2010; Nishihama et al. 2015). All these researches have provided fundamental data on different environmental factors controlling life cycle phases as spore germination and protonemal development of certain moss species.

However, no studies have been performed to understand spore germination and protonemal development of the endemic and threatened $D$. diversiformis (Wei et al. 2007). Whether environmental factors, such as light and temperature, can control these developmental processes, is unknown. In our study, we report in vitro culture of this species and characterize spore germination and protonemal development of $D$. diversiformis. In addition, we report effects of light and temperature on these two developmental processes.

\section{MATERIAL AND METHODS}

Dolichomitriopsis diversiformis plants were collected from Fanjin Mountain, Guizhou Province, China in September, 2013. Plants grew on the bark surface of basal trunks of two tree species, Cyclobalanopsis stewardiana and Fagus lucida, two evergreen broadleaf plants of which were growing at the altitude of $1760 \mathrm{~m}$. When collected, the moss was at the stage of immature green sporophytes, which were characterized by clusters. In addition, sporophytes were collected from six trunks as biological replicates. The collected immature greenish sporophytes were then placed in growth room at room temperature and supplemented with natural light. After 50 days, capsules turned into orange color, indicating maturity. 
The agar solidified medium prepared using a modified Knop's solution and spore inoculation methods were as described previously Zhao et al. (2004). Medium was contained in disposable Petri dishes (90 $\mathrm{mm}$ in diameter and $15 \mathrm{~mm}$ in depth). Petri dishes were placed in the continuous light condition in a growth chamber. Spore germination and development was observed under microscope and pictures were taken to record and characterize development processes.

For comparison of light and darkness, four petri dishes, each as one replicate for each treatment, were placed in each condition. The light condition was carried out in two growth chambers one facilitated with $24 \mathrm{~h}$ light $\left(20 \mu \mathrm{mol} . \mathrm{m}^{-2} . \mathrm{s}^{-1}\right)$ at $20 \pm 1$ ${ }^{\circ} \mathrm{C}$ and the other with $24 \mathrm{~h}$ light $\left(20 \mu \mathrm{mol} \cdot \mathrm{m}^{-2} \cdot \mathrm{s}^{-1}\right)$ at $25 \pm 1{ }^{\circ} \mathrm{C}$. The dark condition was performed at 20 $\pm 1{ }^{\circ} \mathrm{C}$ and spores were cultured for 30 days. Then, dark-grown spores were moved to the first growth chamber. In addition, a natural light condition with 11-13 $\mathrm{h}$ photoperiod $\left(20-40 \mu \mathrm{mol} \cdot \mathrm{m}^{-2} \cdot \mathrm{s}^{-1}\right)$ at room temperature of 5-10 ${ }^{\circ} \mathrm{C}$ was used as control.

Spore germination was observed daily for two months. Spore morphological changes and protonema development were observed and photographed using a LEICA microscopy. The germination rate was calculated as the total number of spores germinating divided by the total number of spores on each petri dish. Twenty spores from each petri dish were randomly selected, and their size, protonema length, number of branches were documented for the period of the experiments. Mean values were calculated to compare effects of different conditions on these parameters. Four replicates for each treatment.

\section{RESULTS}

\section{SPORE GERMINATION, PROTONEMA GROWTH AND GAMETOPHYTE FORMATION}

Under continuous light condition at $20{ }^{\circ} \mathrm{C}$, spores of D. deversiformis were 23-24 $\mu \mathrm{m}$ (Table 1) in diameter with a spherical or subsphaeroidal shape. They had a greenish color resulted from the abundance of chloroplasts (Fig. 1a). Table 1 showed the mean size of 20 spores in different treatments.

The spore germination was characterized by different morphological changes under continuous light at $20{ }^{\circ} \mathrm{C}$. First, spores started to swell gradually. During the swelling period, the exine broke and the intine structures disrupted subsequently and the number of chloroplasts increased obviously. Second, protoplasts protruded to form a filamentous germ tube. Third, as more cell divisions proceeded at the top of tube, multicellular filamentous gametophytes, e.g. chloronema, were established, with features of hyaline cell walls, transversely placed cross walls, and numerous rounded chloroplasts (Fig.1b). During this state, the size of chrolonema cell was $31.0-38.0 \mu \mathrm{m} \times 11.0$ $16.0 \mu \mathrm{m}$, larger and longer at the basal cells and 20 ${ }^{\circ} \mathrm{C}$ (Tab. 1). The polarity of spore germination was monopolar at early stages, bipolar after 16 days later, while tripolar was rarely occurred.

Table 1 Size $(\mu \mathrm{m})$ of spore and chloronema cell under different treatments

\begin{tabular}{|c|c|c|c|c|c|c|}
\hline \multirow{2}{*}{$\begin{array}{l}\text { DAYS OF } \\
\text { TREATME } \\
\text { NT }\end{array}$} & \multicolumn{2}{|c|}{24 H LIGHT/ $20^{\circ} \mathrm{C}$} & \multicolumn{2}{|c|}{24 H LIGHT/ $25^{\circ} \mathrm{C}$} & \multirow{2}{*}{$\begin{array}{l}\text { NATURAL } \\
\text { LIGHT /5-10 } \\
{ }^{\circ} \mathrm{C} \\
\text { Spore }\end{array}$} & \multirow{2}{*}{$\begin{array}{l}\text { DARKNESS } \\
{ }^{\circ} \mathrm{C} \\
\text { SPORE }\end{array}$} \\
\hline & Spore & Protonema & Spore & Protonema & & \\
\hline O D & $23.6 \times 23.6$ & - & $236 \times 23$ & - & $23.6 \times 23.6$ & 23.6×23.6 \\
\hline $4 \mathrm{D}$ & $27.6 \times 24.8$ & $35.8 \times 15.7$ & $26.0 \times 26.0$ & $31.9 \times 11.1$ & $24.5 \times 23$ & $24.3 \times 23.9$ \\
\hline $7 \mathrm{D}$ & $30.7 \times 26$. & $37.9 \times 13.2$ & $30.3 \times 26.0$ & $33.4 \times 15.1$ & $24.9 \times 24.8$ & $25.0 \times 24.7$ \\
\hline $10 \mathrm{D}$ & $34.6 \times 33.0$ & $37.8 \times 15.3$ & $31.0 \times 30.1$ & $34.8 \times 14.7$ & $25.7 \times 25.5$ & $25.8 \times 25.4$ \\
\hline 13 D & & $31.3 \times 11.9$ & & $35.2 \times 11.5$ & & \\
\hline
\end{tabular}

Note: Size of chloronema was the mean value of the first five cells attached to the spore. 


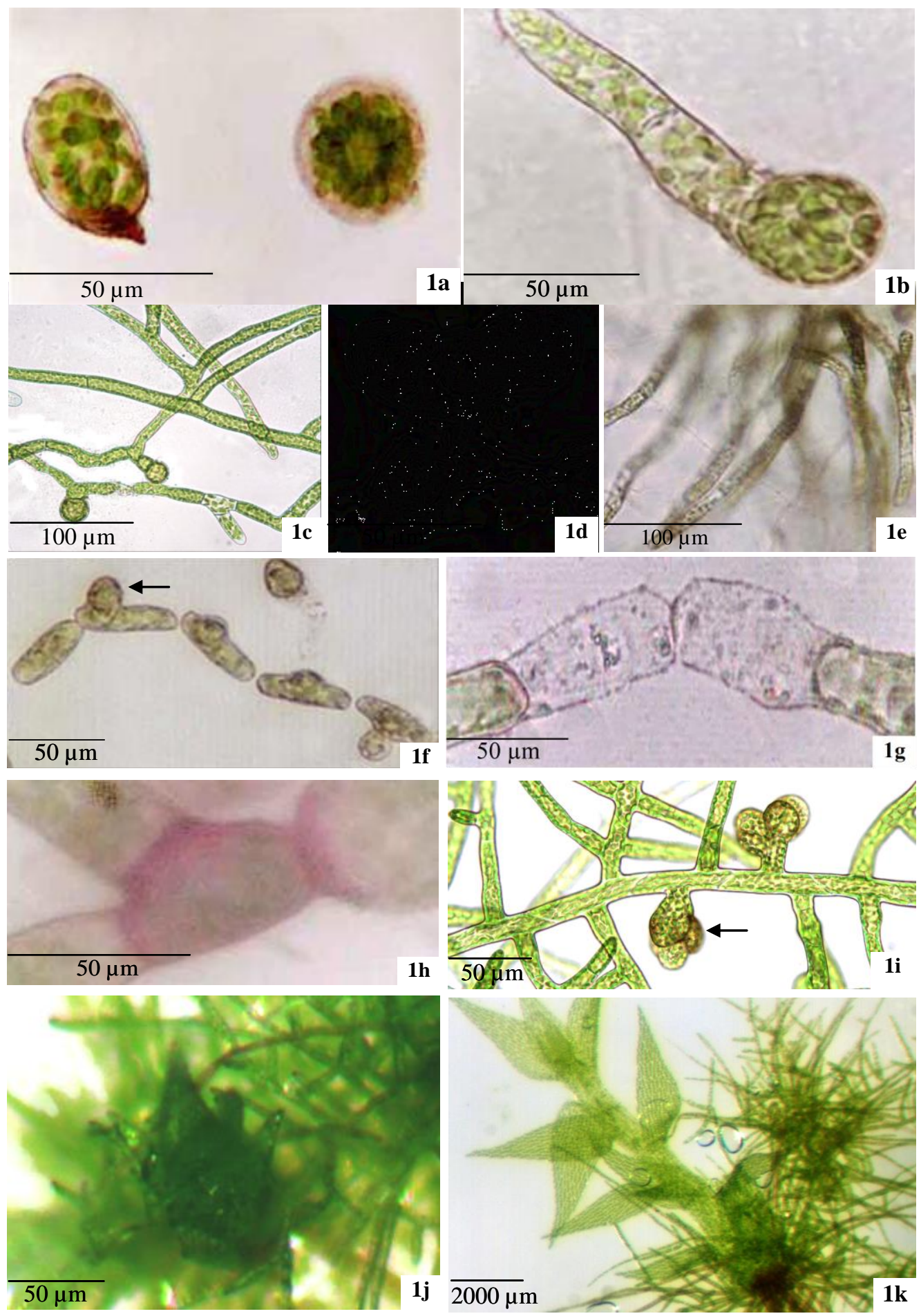

Figure 1: Fig.1a. Spores of D. diversiformis; Fig.1b. A chloronemal filament produced from germinating spore after 4 days; Fig.1c. Branched chloronema; Fig.1d Chloronemal branches grew aerially; Fig.1e. Rhizoid-like branches grew into media. Fig.1f. Short cylindrical brood cells that were detached from mother protonema filament and regenerated into new filament cell by tip-growing (arrow); Fig.1g. Tmema cells, with remnant protoplast and cell wall; Fig.1h. Brown-pigmented cell, 4-6 wedge-shaped, with thickened walls; Fig.1i. Gametophore primordium cell (arrow) produced from caulonema. Fig.1j. Gametophore bud. Fig.1k. Young gametophyte plant with stem and leaves.

After seven days, most chloronemata produced branches at the basal cells. Some of chloronema grew up to $200 \mu \mathrm{m}$ in length (Fig.1c). After 30 days,

the filamentous chloronema differentiated into two parts creeping or erecting aerial sections (Fig. 1d) and the rhizoid-like sections in the medium. The 
formers were rich in chloroplasts, while the later lacked chloroplasts (Fig. 1e). In addition, the formers produced secondary and tertiary branches up to 70 filamentous structures, which were shown by a villiform colony of 1-2 $\mathrm{mm} \times 2-2 \mathrm{~mm}$ in size.

During development, other morphological changes were observed. After the growth of 18 days, certain cells close to the basal parts of chloronemata detached from each other and developed into separated brood cells. As a consequence, the previous long filaments transformed into chains of short cylindrical brood cells (Fig. 1f). Brood cells were capable of developing new cholonema after 10 days. Meanwhile, some aplastidic abscission (tmema) cells were observed after the 37 days of growth. The protoplasts of two adjacent tmema cells disintegrated and dissolved, leaving remnants of the cell wall (Fig. 1g), while the neighbor cells remained normally. The occurrence of tmema cells made a longer chloronema separate into a couple of shorter ones, and lose of the integrity of the original filaments. However, the remained chloronemata could produce new chloronemata in the latter stages.

Caulonema that is a pre-requisite for formation of gametophore bud was also observed after 40 days of growth in our experiment. Caulonema developed from chloronema, which were featured by decreased number of spindle-shaped chloroplasts and obliquely placed cross walls (Fig. 1i). Afterwards, some 4-6 wedge-shaped, with thick, dark brown-pigmented wall cells appeared at the basal or middle parts of a filament (Fig. 1h). Seventy days later, a type of large gametophore primordium cells with big chloroplasts and thick cytoplasm were developed from the basal cells of filamentous caulonemata (Fig. 1i). These cells divided in various directions to form a multicellular mulberry-like structure with plentiful chloroplasts, and then developed into a gametophore bud (Fig. 1j). New stems, leaves, and transparent rhizoids were formed from these new buds. At this end, young gametophytes with greenish leaf-like structures were fully developed (Fig. 1k).

\section{EFFECTS OF LIGHT AND TEMPERATURE ON SPORE GERMINATION AND PROTONEMAL DEVELOPMENT}

Light, dark and two temperatures were compared to understand their effects on spore germination and protonemal development. Effects of light and dark cultures on spore germination were performed at 20 ${ }^{\circ} \mathrm{C}$. The resulting data showed that no spore germination was observed in the dark culture after inoculation for 1-30 days. In contrast, spores started to germinate after 24 hours culture in the light condition (table 2). It was interesting that when dark-cultured spores after 30 days of inoculation were moved to the light condition, spores started to germinate in 48 hours. These results indicated that light controls spore germination. In addition, different germination rates in the light conditions were observed (table 2).

In the light condition, three temperatures were compared to understand their effects on spore germination. Data were summarized for germination rates observed after 4, 7, 10, 13, 18, 24, 30 and 56 days of inoculation. The resulting data showed that on day 13 , most of spores germinated at both 20 and $25{ }^{\circ} \mathrm{C}$ conditions, while about $35 \%$ germination rate at $5-15{ }^{\circ} \mathrm{C}$. After 56 days of inoculation, the germination rates at three temperature conditions were similar. These data indicate that temperature controls germination time.

\begin{tabular}{|c|c|c|c|c|c|}
\hline $\begin{array}{lr}\text { DAYS OF } \\
\text { TREATMENT }\end{array}$ & $\begin{array}{l}\text { NATURAL LIGHT } \\
/ 5-10{ }^{\circ} \mathrm{C}\end{array}$ & $\begin{array}{l}\text { 24H LIGHT } \\
/ 20^{\circ} \mathrm{C}\end{array}$ & $\begin{array}{l}\text { 24H LIGHT } \\
/ 25^{\circ} \mathrm{C}\end{array}$ & $\begin{array}{l}\text { DARKNESS } \\
/ 20^{\circ} \mathrm{C}\end{array}$ & $\begin{array}{l}\text { DARKNESS MOVED TO } \\
24 \mathrm{H} \text { LIGHT } \\
/ 20{ }^{\circ} \mathrm{C}\end{array}$ \\
\hline $4 \mathrm{D}$ & 0.0 & $83.3 \pm 5.36$ & $84.5 \pm 4.62$ & 0.0 & $81.6 \pm 6.31$ \\
\hline $7 \mathrm{D}$ & 0.0 & $86.7 \pm 4.45$ & $88.2 \pm 5.32$ & 0.0 & $87.6 \pm 2.54$ \\
\hline $10 \mathrm{D}$ & 0.0 & $91.4 \pm 4.86$ & $92.4 \pm 4.81$ & 0.0 & $90.3 \pm 5.37$ \\
\hline 13 D & $35.4 \pm 6.31$ & $92.3 \pm 5.27$ & $93.8 \pm 7.19$ & 0.0 & $91.6 \pm 7.56$ \\
\hline $18 \mathrm{D}$ & $70.2 \pm 5.62$ & - & - & 0.0 & - \\
\hline $24 \mathrm{D}$ & $81.5 \pm 4.33$ & - & - & 0.0 & - \\
\hline $30 \mathrm{D}$ & $86.7 \pm 6.84$ & - & - & 0.0 & - \\
\hline $56 \mathrm{D}$ & $90.8 \pm 5.67$ & $95.3 \pm 3.32$ & $96.1 \pm 1.24$ & - & - \\
\hline
\end{tabular}

Effects of temperature treatments on protonemal development and branching capacity were observed in different light condition. The resulting data showed that continuous light and $20{ }^{\circ} \mathrm{C}$ is an appropriate condition for elongation (Fig. 2). After 57 days of growth, protonema grew nearly $1700 \mu \mathrm{m}$ 
at the $57^{\text {th }}$ day. In comparison, other conditions slowed down the protonemal elongation.

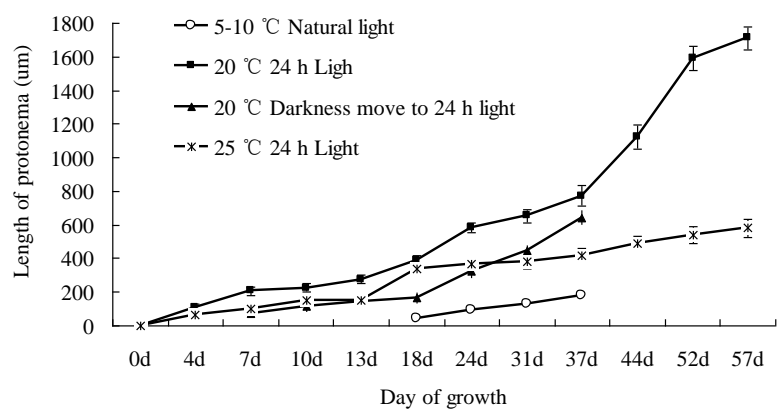

Figure 2 Effects of light and temperature on growth of protonema (mean \pm std)

In addition, branch numbers were recorded to observe effects of three conditions on branching. The resulting data showed that light and $20{ }^{\circ} \mathrm{C}$ was an appropriate condition for branching. After 37 days of inoculation, approximately 65 branches were developed from one protonema under this condition (Table 3). In comparison, two other conditions reduced branching capacity (table 3 ).

Table 3 Effects of light and temperature on the number of branches of a colony

\begin{tabular}{l|lll}
\multicolumn{1}{l}{} & \multicolumn{1}{l}{ / 24H LIGHT } & / 24H LIGHT & \multicolumn{2}{l}{ / DARKNESS MOVED TO 24 H LIGHT } \\
\hline 4 D & $1.0 \pm 0.0$ & $1.0 \pm 0.0$ & $\mathbf{1 . 5} \pm \mathbf{0 . 0}$ \\
7 D & $2.0 \pm 0.2$ & $1.3 \pm 0.2$ & - \\
10 D & $3.2 \pm 0.2$ & $1.4 \pm 0.2$ & $\mathbf{3 . 5} \pm \mathbf{0 . 2}$ \\
13 D & $4.1 \pm 0.1$ & $1.6 \pm 0.2$ & - \\
18 D & $12.5 \pm 1.5$ & $4.5 \pm 1.0$ & $\mathbf{5 . 2} \pm \mathbf{0 . 8}$ \\
24 D & $23.6 \pm 2.3$ & $4.9 \pm 1.1$ & - \\
31 D & $45.2 \pm 4.7$ & $10.8 \pm 2.4$ & $\mathbf{3 0 . 2} \pm \mathbf{2 . 5}$ \\
37 D & $64.8 \pm 11.4$ & $27.7 \pm 6.7$ & $\mathbf{5 8 . 7} \pm \mathbf{9 . 8 1}$
\end{tabular}

\section{DISCUSSION}

Bryophyte plants are characterized by dominant and elaborated gametophytes and subordinate sporophytes, in which the later ones are attached the former ones throughout its life cycle. Gametophytes produce haploid sperm and eggs which fuse to form diploid zygotes that grow into sporophytes. Sporophytes produce haploid spores by meiosis that grow into gametophytes (Ray et al., 1983). Based on morphological properties that are documented in textbooks, it is apparent that bryophyte plants are unique in the plant kingdom that when a germinated spore develops into a gametophyte, the protonemal stage was absolutely necessary to finish the life cycle. Nishida (1978) described the features of spore germination and protonemal development of 121 species of mosses, and placed these features into 13 sporeling types. By referring to the criterion of Nishida (1978), we deduced the germination type of $D$. diversiformis was exosporous, and the sporeling pattern could be classified as bryum-type (Fig. 1a, 1b).

$D$. diversiformis is an endemic species in southeastern China (Wei et al., 2007). But its environmental habitation is threatened by air pollution and deforestation. In this study, we developed in vitro culture conditions to study its spore morphology, germination and development.
As described in results, light essentially controls spore germination. This phenomenon has been proposed to be likely associated with a series of physiological processes. Glime (2015) recently reviewed that the spore activation is regulated by energy supply in chloroplast during the green spore germination. In addition, this review summarized that biosynthesis of plant hormones such as GA and IAA in the light condition can facilitate spore germination. It can be expected that as more molecular evidence will be reported, the mechanisms of spore germination will be elucidated. Temperature also controls germination and protonemal development. The effects of temperature on development has been reported in other investigations. Glime $(2013,2015)$ also recently reviewed that when temperature is relatively low, germinated spores or developed protonemata can be frozen or delayed. Our results from low temperature treatment support this conclusion. These data will help develop strategies to protect this moss species. In addition, our results are helpful to propagation of this moss in the future. For example, we observed brood cell formation during the protonemal development. The formation of brood cell was invariably associated with a slowing down or cessation of protonemal tip growth and was mostly confined to chloronemal filaments or side branches. Brood cells were existed widely in 
protonemal colonies in vitro and in field, for long periods of suboptimal conditions, e.g. ageing, drying out and liquid cultures, to adapt the desiccation processes (Duckett et al. 2004). ABA (abscisic acid) seemed triggering a random microfibril deposition in the protonema cells, and the mechanism by which cellulose deposition without organization could be related to a microtubular configuration with no preferred orientation (Goode et al. 1993). From the point of view of propagation, each of the segmented brood cells from parent filament redifferentiated into a new protonema, could be considered as a reproductive strategy for the moss to increase its population.

\section{CONCLUSIONS}

Spores of $D$. diversiformis and sporeling pattern were morphologically characterized to be a bryumtype. Light promoted but dark inhibited spore germination. Temperature also controls spore germination and protonemal development. This work will promote propagation of this moss species and enhance conservation of species.

\section{ACKNOWLEDGEMENTS}

Financial support for this research was provided by the National Science Foundation of China (No.30470181) and the Key Course of Hunan Province (Ecology). We are thankful to Professor De-Yu Xie from North Carolina State University for critically editing our manuscript and suggestions.

\section{REFERENCES}

Alfayate C, Ron E, Estébanez B, Pérez-Batista MÁ. Mature spores of four pleurocarpous mosses in the Canary Islands: ultrastructure and early germination stages. Bryologist. 2013; 116 (2): 97 112.

Bauer IE, Tirlea D, Bhatti JS, Errington RC. Environmental and biotic controls on bryophyte productivety along forest to peatland ecotones. Can J Bot. 2007; 85: 463-475.

Bureau of National Environmental Protection. The situation research report on Chinese biodiversity. Beijing: Chinese Environmental Science Press. 1998.
Chaban CI, Ripetskyj RT, Kordyum EL, Kit NA. High temperature alters the growth reaction of Pottia Protonemata. Adv Space Res. 1999; 23 (12): 2011 2016.

Chen LZ. Biodiversity in China - actualities and protective strategies. Beijing: Science Press. 1993.

Chopra RN, Bhatla SC. Effect of physical factors on gametangical induction, fertilization and sporophyte development in the moss Bryum argenteum grow in vitro. New Phytol. 1981; 89: 439-447.

DU XM, Li J, Tian XR, Li ZY, Li HM. Influence of dehydration and rehydration on photosynthetic chlorophyll characteristics and reactive oxygen species metabolism in Dolichomitriopsis diversiformis. Acta Eco Sin. 2014; 34 (23): $6807-$ 6816.

Duckett JG, Burch J, Fletcher PW, Matcham HW, Read DJ, Russell AJ, et al. In vitro cultivation of bryophytes: a review of practicalities, problems, progress and promise. J Bryol. 2004; 26:3-20.

Duckett JG, Ligrone R. A survey of diaspore liberation mechanisms and germination patterns in mosses. $J$ Bryol. 1992; 17:335-354.

Glime, JM. Ecophysiology of Development: Protonemata. Chapt 5-3. In: Glime, JM. Bryophyte Ecology. Volume 1. 5-3-1 Physiological Ecology. Ebook sponsored by Michigan Technological University and the International Association of Bryologists. Last updated 23 September 2013. Available from: http: //www.bryoecol.mtu.edu.

Glime, JM. Ecophysiology of Development: Spore Germination. Chapter 5-2. In: Glime, JM. Bryophyte Ecology. Volume 1. 5-2-1 Physiological Ecology. Ebook sponsored by Michigan Technological University and the International Association of Bryologists. Last updated 3 March 2015. Available from: http: //www.bryoecol.mtu.edu.

Gong SJ, Ma TW, Li J, Liu YD. Leaf cell damage and changes in photosynthetic pigment contents of three moss species under cadmium stress. Chin J Appl Eco. 2010; 21 (10): 2671-2676.

Goode JA, Stead AD, Duckett JG. Redifferentiation of moss protonemata: an experimental and immunofluorescence study of brood cell formation. Can J Bot. 1993; 71:1510-1519.

Hohe A, Reski R. From axenic spore germination to molecular farming. Plant Cell Rep. 2005; 23: 513521.

Li J, Wei H, Liu B, Wang YQ, Chen J. Study on the reproductive allocation pattern of nutrients in Dolichomitriopsis diversiformis (Bryopsida: Lembophyllaceae). Acta Bot Yunnan. 2009; 31(3): 219-226.

Li YJ, Li J, Chen J, Huang GW. Response of Dolichomitriopsis deversiformis photosynthesis 
rate to light, air temperature and pant water content. Chin J Appl Ecol. 2004; 15 (3): 391-395.

Liu B, Jiang YF, Li J, Huang H, Chen J. A study on distribution pattern of an epiphytic bryophyte, Dolichomitriopsis diversiformis (Lembophyllaceae) on tree trunks in forest in Fanjing Mountain of Guizhou. Acta Bot Yunnan. 2006; 28 (2): 169-174.

Liu B, Li J, Tian QJ, Chen J. Sex ratios and rate of sexual reproduction in the epiphytic moss Dolichomitriopsis deversiformis. Guihaia. 2008; 28 (4): 440-442.

Mallón R, Reinoso J, Rodríguez-Oubiña J, González ML. In vitro development of vegetative propagules in Splachnum ampullaceum: brood cells and chloronemata bulbils. Bryologist. 2006; 109 (2): 215-223.

Martinez K, Price M. Brood cells in the rare, epiphytic moss Tayloria rudolphiana (Garov.) Bruch et Schimp (Splachnaceae). Cryptogamie. Bryol. 2011; 32 (1): 3-12.

Nishida Y. Studies on the sporing types in mosses. $J$ Hattori Bot Lab. 1978; 44:371-454.

Nishihama R, Ishizaki K, Hosaka M, Matsuda Y, Kubota A, Kohchi T. Phytochrome-mediated regulation of cell division and growth during regeneration and sporeling development in the liverwort Marchantia polymorpha. J Plant Res. 2015; 128: 407-421.

Noguchi A. Illustrated moss flora of Japan. Part 3: Distribution of Dolichomitriopsis diversiformis (Mitt.) Nog.: Japan, Korea. Hattori Botanical Laboratory, Nichian, Miyazaki, Japan. 1989. p.728.

Nowak U, Mlodzianowski F. The influence of kinetin on regeneration of the protonema from isolated protoplasts of the moss Funaria hygrometrica L. Sibth. Acta Soc Bot Pol. 2014; 49 (3): 195-203.

Pressel S, Ligrone R, Duckett JG. The differentiation of moss protonemata: a cytological and experimental study. Ann Bot. 2008; 102: 227-245.

Ray PM, Steeves TA, Fultz SA. Chapter 27 Bryophytes: Nonvascular Land Plants. In: Ray PM, Steeves TA, Fultz SA. Editor. Botany. New York: Saunders College Publishing, 1983. p. 529.

Sabovljević M, Vujičić M, Pantović J, Sabovljević A. Bryophyte conservation biology: In vitro approach to the ex situ conservation of bryophytes from Europe. Plant Biosyst. 2014; 148 (4): 857-868.

Silva ASM, Cavalcanti PK, Simabukuro EA. Effects of light and nutrients on different germination phases of the Cosmopolitan moss Bryum argenteum Hedw. (Bryaceae). Braz Arch Biol Technol. 2010; 53 (4): 763-769.

Wei H, Li J, Chen J, Jiang YF. Study on the characteristics of protonema development in Dolichomitriopsis diversiformis. J Wuhan Bot Res. 2007; 25 (2): 169-172.
Wu P C. The East Asiatic genera and endemic genera of the bryopytes in China. Bryobrothera. 1992; 1: 99117.

Wu SP, Qin ZZ, Xiao TZ, Li QP, Lu BB, Jing LJ, et al. Cryopreservation of gemmae of Marchantia polymorpha L. (Marchantiophyta, Marchantiaceae) without prior pretreatment. Cryoletters. 2015; 36 (2): $91-96$

Zhang N, Du BM, Ji MC. Research progress on the bryophytes tissue culture. J Zhejiang A \& F Univ. 2011; 28 (2): 305-313.

Zhao JC, Huang SL, Li M, Sulayman M, He J, Zhang YM, et al. A study on the characteristics of spore germination and protonemal development in Lindbergia brachyptera. Arctoa. 2004; 13: 223 228.

Zhou ZX. Research on the Fanjin Mountains. Guiyang: Guizhou Peoples Press. 1990.

Received: January 15, 2016; Accepted: April 25, 2016 